\title{
Relieving efforts in palm-tree tissue sampling for population genetics analyses.
}

\author{
Sebastian Espinoza-Ulloa ${ }^{1}$ \\ ${ }^{1}$ University of Saskatchewan
}

November 21, 2020

\begin{abstract}
The young leaves are the main source of nucleic acids for population genetic studies in palm-trees; however, the access to this tissue may be limited by specific features of each species. Using root tissues as an alternative source of nucleic acids could facilitate the sampling in large populations. This study tests root tissue viability as an alternative nucleic acids source (root vs. leaf) and explores different protocols (tissue storage and DNA purification methods) to obtain high-quality DNA samples. The results showed no significant differences in DNA concentration and quality for the comparisons of tissue source (leaf vs. root) and DNA purification method (manual vs. kit). For tissue storage method, DNA concentration was significantly higher for root tissues stored in $70 \%$ and $90 \%$ alcohol solutions versus those obtained from leaf tissue, however for the quality parameters, no differences were found. Results showed the effective potential of using root tissue as an alternative source for nucleic acids, which could facilitate populations sampling of palm-tree species for future studies and this methodological alternative could be applied to other plant systems with similar sampling challenges.
\end{abstract}

\section{Relieving efforts in palm-tree tissue sampling for population genetics analyses.}

\section{Sebastian A. Espinoza-Ulloa ${ }^{1,2}$}

${ }^{1}$ Facultad de Medicina. Pontificia Universidad Católica del Ecuador. Avenida 12 De Octubre 1076, EC 170143. Quito, Ecuador.

${ }^{2}$ Department of Biology. University of Saskatchewan. Collaborative Science Research Building, 112 Science Place. S7N 5E2. Saskatoon, SK. Canada.

Received: ; Revised: ; Accepted:

\section{ABSTRACT}

1. The young leaves are the main source of nucleic acids for population genetic studies in palm-trees; however, the access to this tissue may be limited by specific features of each species. Using root tissues as an alternative source of nucleic acids could facilitate the sampling in large populations.

2. This study tests root tissue viability as an alternative nucleic acids source (root vs. leaf) and explores different protocols (tissue storage and DNA purification methods) to obtain high-quality DNA samples.

3. The results showed no significant differences in DNA concentration and quality for the comparisons of tissue source (leaf vs. root) and DNA purification method (manual vs. kit). For tissue storage method, DNA concentration was significantly higher for root tissues stored in $70 \%$ and $90 \%$ alcohol solutions versus those obtained from leaf tissue, however for the quality parameters, no differences were found.

4. Results showed the effective potential of using root tissue as an alternative source for nucleic acids, which could facilitate populations sampling of palm-tree species for future studies and this methodological alternative could be applied to other plant systems with similar sampling challenges. 


\section{KEYWORDS:}

Sampling methods, population genetics, palm-tree, root tissue, DNA methods.

\section{INTRODUCTION}

For population genetics, the experimental design for plant tissue sampling can be affected mainly by individuals' density, the proximity between individuals, the topography, and the access to the tissue to be sampled. Additionally, in palm-trees, the sampling of fresh tissue rich in nucleic acids may be hindered by the specific features of each species. Traditionally in plants, tissue samples with high concentrations of nucleic acids are obtained from meristematic tissue of new shoots or leaves (Edwards et al ., 1991; Tai \& Tanksley, 1990; Tapia-Tussell et al ., 2005). In palm-trees, new leaves originate from meristematic tissue located in the center of the crown. For most species, access to this tissue requires an extraordinary sampling effort due mainly to stem height, stem modifications (spines or prominent scars of old leaves) and/or even to high degrees of epiphytism in addition to habitat factors which also can further increase sampling efforts. Such increases in sampling effort often lead to modifications in the experimental design in terms of the number of individuals sampled or the time designated for it (Lowman et al ., 1993).

Taking into account the problems that arise for several palm-tree species, regarding the access to young leaves (or meristematic tissue associated with the crown) and their possible negative implications on the sampling effort for population genetics studies, it is thus necessary to explore alternatives that reduce this effort. For instance, in palms-trees, root tissue would be theoretically an ideal candidate to obtain high concentrations of nucleic acids, but this tissue has not been thoroughly tested with regard to DNA extractability, resulting DNA quality and best extraction and tissue storage protocols. The root apex is mainly formed by meristematic tissue that is in constant formation and replacement. Therefore, it would be expected the terminal region of the root contains high concentrations of nucleic acids mainly from non-specialized cells (Broschat \& Donselman, 1984; Broschat \& Donselman, 1990; Jouannic et al ., 2011). This study aims to test the use of root tissues as an alternative source of nucleic acids. It thus also seeks to establish the best tissue storage and DNA purification methodologies.

\section{MATERIALS AND METHODS}

Four different species of palm-trees (Arecaceae) were used: 1)Phoenix dactylifera, 2) Ceroxylon equinulatum , 3) Ceroxylon ventricosum and 4) Prestoea acuminata. These species are easily found in the Ecuadorian Andean urban and rural landscapes (between 1,800 - 2,500 m.a.s.l.). All these species are conspicuous stem palm-trees that commonly exceed 10 meters in height, and their roots are placed underground.

For sampling, two individuals were selected per species. The tissue collection for each individual was carried out 1) climbing along the stem to obtain young leaf tissue, and 2) using a shovel to dig about $30 \mathrm{~cm}$ in the stem base to obtain root tissue (figure 1). Leaf tissue was stored directly in a single bag with Silica Gel, following the most commonly used protocol for leaf tissue sampling (control sample). For root tissue sampling, eight roots per individual were pruned at $5 \mathrm{~cm}$ from the tip (figure 1), and two pruned roots were placed into each tissue storage treatment $(\mathrm{T}=4)$. The storage treatments for root tissues were: a) Silica Gel dehydration, b) distilled water, 3) $70 \%$ ethanol solution (EtOH 70\%), and d) $90 \%$ ethanol solution (EtOH $90 \%)$. All samples were processed after two weeks of storage.

\section{[Figure 1 about here]}

Each stored tissue underwent two DNA extraction methods: i) DNA extraction manual method for plant tissues based on Doyle \& Doyle (1987, with modifications), and ii) commercial method using PureLink $\mathbb{R}$. Plant Total DNA Purification Kit (Invitrogen ). Each extraction started with $100 \mathrm{mg}$ of macerated tissue. The final DNA extraction solutions were evaluated using NanoDrop 1000 Spectrophotometer (Thermo Fisher Scientific). Three readings for each processed sample were taken.

DNA concentration and quality were compared between tissue sources, storage treatments, and DNA extraction methods. The concentration was measured as DNA nanograms contained in one microliter. The 
quality parameters are based on the A260/A280 and A260/A230 ratios, where A260 is the absorbance at 260 $\mathrm{nm}$ that would be marking the presence of aromatic bases (nucleotides/DNA/RNA), A280 is the absorbance at $280 \mathrm{~nm}$ that would recognize contaminants such as proteins and phenolic compounds, and A230 would identify residual contaminants of many organic compounds such as phenol, TRIzol, salts, among others. In this way, the A260/A280 ratio would be linked to factors related to the nature and processing of the tissue, while the A260/A230 ratio would be linked to the reagents and residues produced by the extraction protocol used (Matlock, 2015).

Finally, as a positive-negative test, a PCR test was performed with two microsatellite loci developed for Oenocarpus bataua (Ob01 and OB11; Montufar et al ., 2007) that had previously been tested and had positive results for all species used in this study. The amplification parameters for these loci were the same described in the source paper.

\section{RESULTS}

For all the samples used, positive results were obtained for DNA extraction. The results for the concentration showed relatively high values for all samples, getting more than $95 \%$ of the samples above $100 \mathrm{ng} / \mu \mathrm{l}$. The leaf tissue mean DNA concentration was $603.71 \mathrm{ng} / \mu \mathrm{l}$, while for root tissue was $599.12 \mathrm{ng} / \mu \mathrm{l}$. For quality, the average for leaf was 2.06 for A260/280 ratio and 2.08 for A260/230 ratio, while for root was 1.91 and 2.03 respectively (Supp. table 1 ).

Regarding the storage treatments, the leaf DNA concentration $(603.71 \mathrm{ng} / \mu \mathrm{l})$ was overcome by all liquid storage treatments for roots: $\mathrm{EtOH} 90 \%(822.57 \mathrm{ng} / \mu \mathrm{l})$, $\mathrm{EtOH} 70 \%(692.84 \mathrm{ng} / \mu \mathrm{l})$, and distilled water $(631.34 \mathrm{ng} / \mu \mathrm{l}$; Supp. table 1; figure 2). On the other hand, for quality, the highest values are for distilled water storage treatment, where the A260/280 ratio was 1.97 and the A260/230 ratio was 2.09, while in leaf they were 2.06 and 2.07 respectively (Supp. table 1; figure 2).

[Figure 2 about here]

The statistical comparison by ANOVA found no significant differences for DNA concentration between leaf and root tissues ( $p=0.927$; Supp. table 2). However, the analysis showed significant differences for DNA concentration between species and storage treatments, also the comparison between extraction methods is at the edge of significance ( $p=0.050$; Supp. table 2). Regarding the A260/280 ratio, there was a significant difference between species, while for tissues the probability was very close to the significance limit $(p=$ 0.053). Finally, for the A260/230 ratio no significant differences were found for all comparisons carried out (Supp. table 2).

As a final result, although no statistical tests were performed, the PCR test for all samples obtained was positive, showing that the DNA solutions obtained did not contain important reaction inhibitors.

\section{DISCUSSION}

Tissues with high cell division rates are the best option in order to get a DNA sample of good concentration and quality, mainly due to the high amount of cells and high replication activity. In plants, this kind of tissues are found in germ buds (meristems), which give rise to newly forming plant organs. In palmtrees, meristematic tissues, in general, are only found in the crown and roots (Arif et al ., 2010; Broschat \& Donselman, 1990). Traditionally, tissue sampling for DNA extraction is obtained from young leaves (that only are found in the crown); however, access can sometimes be quite complicated which could affect negatively the number of sampled individuals (Ihase et al ., 2016). Moreover, easier access to a meristematic tissue for sampling palm-trees would be found in their roots, where is expected to get similar DNA concentration and quality as is obtained from leaves (Broschat \& Donselman, 1984; Jouannic et al ., 2011). The results of this study have shown that obtain DNA from root tissue is not only viable, but that the DNA concentration can be higher and its quality similar to what was obtained from leaf tissue as traditional methodology.

Regarding the source tissue, no differences for DNA concentrations were found between the overall root results with leaf tissue results. However, for quality, the A260/280 ratio borders the limit of significance. 
This almost significant difference may be explained by the higher amount of contaminants (mainly proteins) linked to the root tissue. In most monocotyledons, the roots are constantly growing and to maintain their structure underground, the tissues need to be constituted by higher concentrations of lignin (and other related proteins) compared to the leaves (Abiven et al ., 2011; Hans-Walter \& Piechulla, 2011; Merewitz et al ., 2011). For this reason, it would be expected that the DNA extraction quality from the root is somewhat lower than that was obtained from the leaf tissue. However, the quality could be improved with standardized storage condition and adjusting the extraction protocol.

Regarding the root storage treatments, the general comparison showed significant differences for DNA concentration, while for both quality ratios there were no differences. This would be explained by the degree of stabilization and fixation of nucleic acids that would result from the different treatments used. Within treatments, the most satisfactory outcomes for DNA concentration were yielded by both ethanol solutions (70\% and 90\%). However, a specific comparison between leaf tissue and root tissue stored in ethanol 90\%, showed a significant higher DNA concentration recovered from the root. Ethanol is a tissue fixative, since it dehydrates the tissue violently (exchanging the water from the sample) allowing to maintain the cellular structure and precipitate the nucleic acids, in consequence, higher concentration of ethanol allows to recover more DNA (Bressan et al ., 2014). On the other hand, the least effective result was that obtained with Silica Gel. Silica Gel salt works by dehydrating the tissue to fix the cells and all their components, and it has been a great tool for the fixation of leaf tissues in plants. However, its low effectiveness in root DNA extraction could be explained by the speed of tissue dehydration. Leaf tissue is arranged in layers forming a single almost regular structure, while the root tissue sample is an irregular and cylindrical structure. Therefore, the root sample will take more time for dehydration, which would allow the breakdown of nucleic acids (Arif et al ., 2010; Bressanet al ., 2014; Jouannic et al ., 2011; Tai \& Tanksley, 1990).

Finally, the comparison between species demonstrated significant differences for concentration, as well as for quality (A260/280), which would be explained by the intrinsic characteristics of each species. Tissues of each species will differ in their shape, composition and cellular structure; therefore, it is understandable that a specific quantity and quality of DNA is recovered from each species according to the specific nature of their tissues (Abiven et al ., 2011; Tapia-Tussell et al ., 2005).

In conclusion, this short experiment proved that it is possible to obtain a "good" DNA sample from palmtree root tissue. This fact could facilitate palm-tree population sampling for large-scale studies by reducing the sampling efforts. Additionally, the storage treatment experiments provide a basis for development of an effective, standardized protocol to obtain best DNA possible for further processing (even for genomic analyses) despite of species or DNA extraction (purification) method.

\section{FIGURES}

\section{Hosted file}

image1.emf available at https://authorea.com/users/377650/articles/494289-relieving-effortsin-palm-tree-tissue-sampling-for-population-genetics-analyses

Figure 1. A) For root sampling, the soil in the base of the palm-tree stem was removed digging about $30 \mathrm{~cm}$ to expose the roots. B) The tissue sampling consisted of prune the final $5 \mathrm{~cm}$ of the root and store it in the different treatments. 

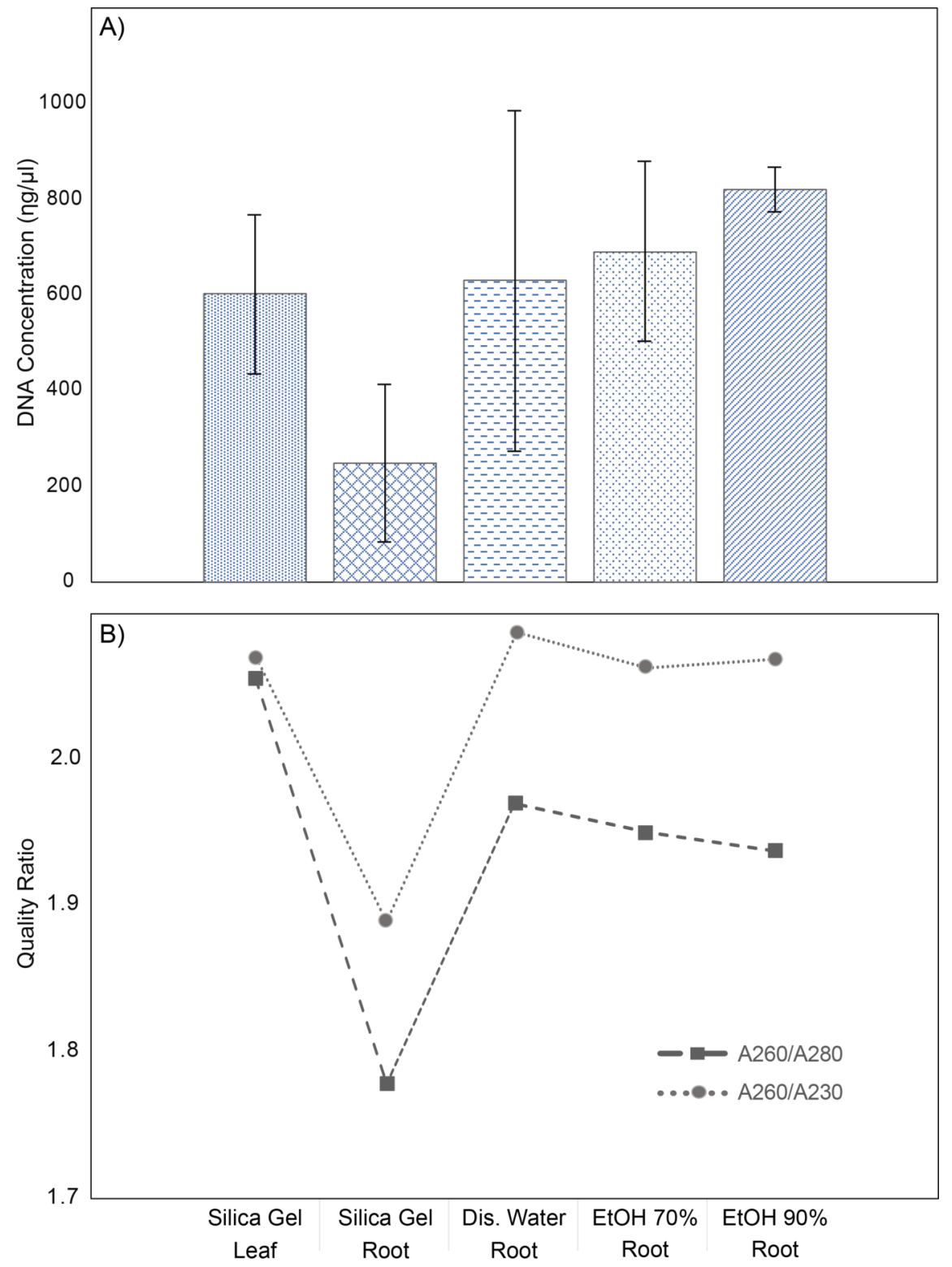

Figure 1. A) DNA concentration (ng/ul) means and their $95 \%$ confidence intervals for each tissue-treatment. B) Quality ratios, A260/280 (squares-lines) and A260/230 (circles-dots), for each tissue-treatment. Tissuetreatments are set as follows: 1) Leaf-Silica Gel $(\mathrm{n}=48), 2)$ Root-Silica Gel $(\mathrm{n}=48), 3)$ Root-Distillated Water $(\mathrm{n}=48), 4)$ Root-EtOH70\% ( $\mathrm{n}=48)$ and 5) Root-EtOH90\% ( $\mathrm{n}=48)$.

\section{ACKNOWLEDGMENTS}

This research was supported by the Pontificia Universidad Catolica del Ecuador (PUCE). I would like to say thank you to this institution, and specifically to Ph. D. Rommel Montufar, director of Molecular Ecology Laboratory where this research was carried out. I thank my lab colleague Jalil Maiguashca who provided insight and expertise that assisted the development of this research. I thank my colleague Jana Ebersbach for helping me with the checking and formatting of this document.

\section{DISCLOSURE STATEMENTS}


None. There is not a conflict of interest.

\section{DATA ACCESSIBILITY}

The data set as well as the detailed statistics output is available at: https://github.com/Sebastardito/Palmtree_Root_Sampling.git

\section{REFERENCES}

Abiven, S., Heim, A. \& Schmidt, M.W.I. (2011) Lignin content and chemical characteristics in maize and wheat vary between plant organs and growth stages: consequences for assessing lignin dynamics in soil. Plant and Soil 343(1-2), 369-378. https://doi.org/10.1007/s11104-011-0725-y

Arif, I. A., Bakir, M. A., Khan, H. A., Ahamed, A., Al Farhan, A. H., Al Homaidan, A. A., Al Sadoon, M., Bahkali A. H. \& Shobrak, M. (2010) A simple method for DNA extraction from mature date palm leaves: impact of sand grinding and composition of lysis buffer. International journal of molecular sciences 11(9), 3149-3157. doi:10.3390/ijms11093149

Bressan, E. A., Rossi, M. L., Gerald, L. T. \& Figueira, A. (2014) Extraction of high-quality DNA from ethanol-preserved tropical plant tissues. BMC research notes 7, 268. doi:10.1186/1756-0500-7-268.

Broschat, T.K. \& H. Donselman. (1984) Root regeneration in transplanted palms. Principles 28:90-91.

Broschat, T.K. \& H. Donselman. (1990) IBA, plant maturity, and regeneration of palm root systems. HortScience 25:232.

Doyle, J.J. \& Doyle, J.L. (1987) A rapid DNA isolation procedure for small quantities of fresh leaf tissue. Phytochemical Bulletin 19(1): 11-15.

Edwards, K., Johnstone, C., \& Thompson, C. (1991) A simple and rapid method for the preparation of plant genomic DNA for PCR analysis. Nucleic acids research 19(6), 1349. doi:10.1093/nar/19.6.1349.

Hans-Walter, H. \& Piechulla B. (2011) 14 - Products of nitrate assimilation are deposited in plants as storage proteins. Plant Biochemistry (Fourth Edition) 2011 (pp. 349-357). Elsevier Inc.

Ihase OL, Horn R, Anoliefo GO, Eke CR, Afolabi AS \& Asemota O. (2016) Development of a method for DNA extraction from oil palm leaves and the effects of $\mathrm{pH}$ and ionic strength on nucleic acid quantification. Journal Biological Methods, 3(2), e37. doi: 10.14440/jbm.2016.80

Jouannic, S., Lartaud, M., Herve, J., Collin, M., Orieux, Y., Verdeil, JL. \& Tregear, J. (2011) The shoot apical meristem of oil palm (Elaeis guineensis ; Arecaceae): developmental progression and dynamics. Annals of Botany 108(8), 1477-1487, https://doi.org/10.1093/aob/mcr019

Lowman, M., Moffett, M. \& Rinker, H. (1993) A new technique for taxonomic and ecological sampling in rain forest canopies. Selbyana 14, 75-79. Retrieved from http://www.jstor.org/stable/41760420

Matlock, B. (2015) Assessment of Nucleic Acid Purity. Thermo Fisher Scientific. Wilmington, MA, USA. https://assets.thermofisher.com/TFS-Assets/CAD/Product-Bulletins/TN52646-E- 0215M-NucleicAcid.pdf (accessed Aug 2, 2019).

Merewitz, E. B., Gianfagna, T. \& Huang, B. (2011) Protein accumulation in leaves and roots associated with improved drought tolerance in creeping bentgrass expressing an ipt gene for cytokinin synthesis. Journal of Experimental Botany 62(15), 5311- 5333. https://doi.org/10.1093/jxb/err166

Montufar, R., Mariac, C., Pham, J. \& Pintaud, J. (2007) Isolation of 23 polymorphic microsatellite loci in the Neotropical palm Oenocarpus bataua Martius (Arecaceae). Molecular Ecology Notes, 7: 75-78. doi:10.1111/j.1471-8286.2006.01532.x

Tai, T.H. \& Tanksley, S.D. (1990) A rapid and inexpensive method for isolation of total DNA from dehydrated plant tissue. Plant Molecular Biology Reporter 8(4), 297-303. https://doi.org/10.1007/BF02668766 
Tapia-Tussell, R., Quijano-Ramayo, A., Rojas-Herrera, R., Larque-Saavedra, A. \& Perez-Brito, D. (2005) A fast, simple, and reliable high-yielding method for DNA extraction from different plant species. Molecular Biotechnology 31(2), 137-139. https://doi.org/10.1385/MB:31:2:137

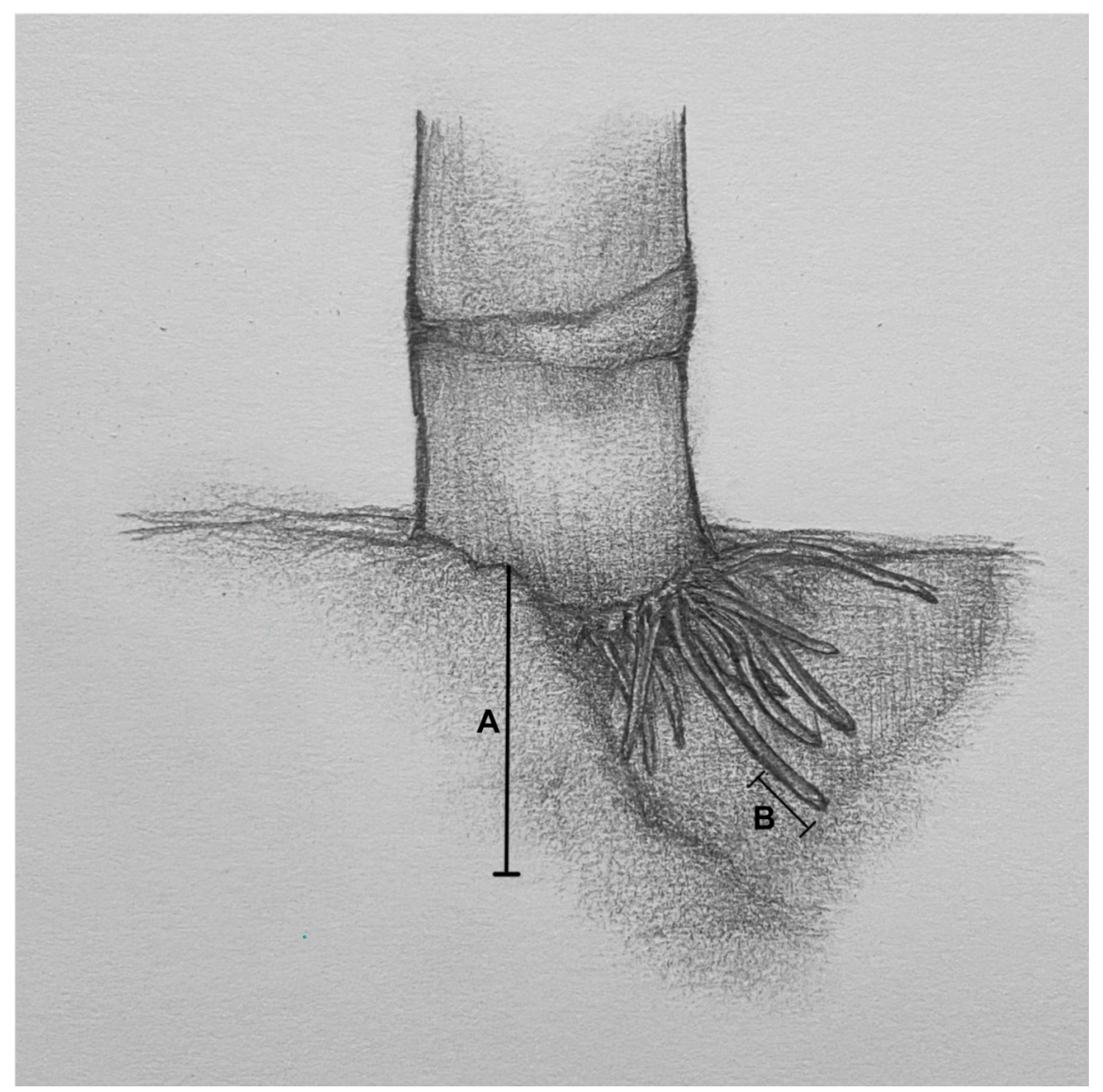



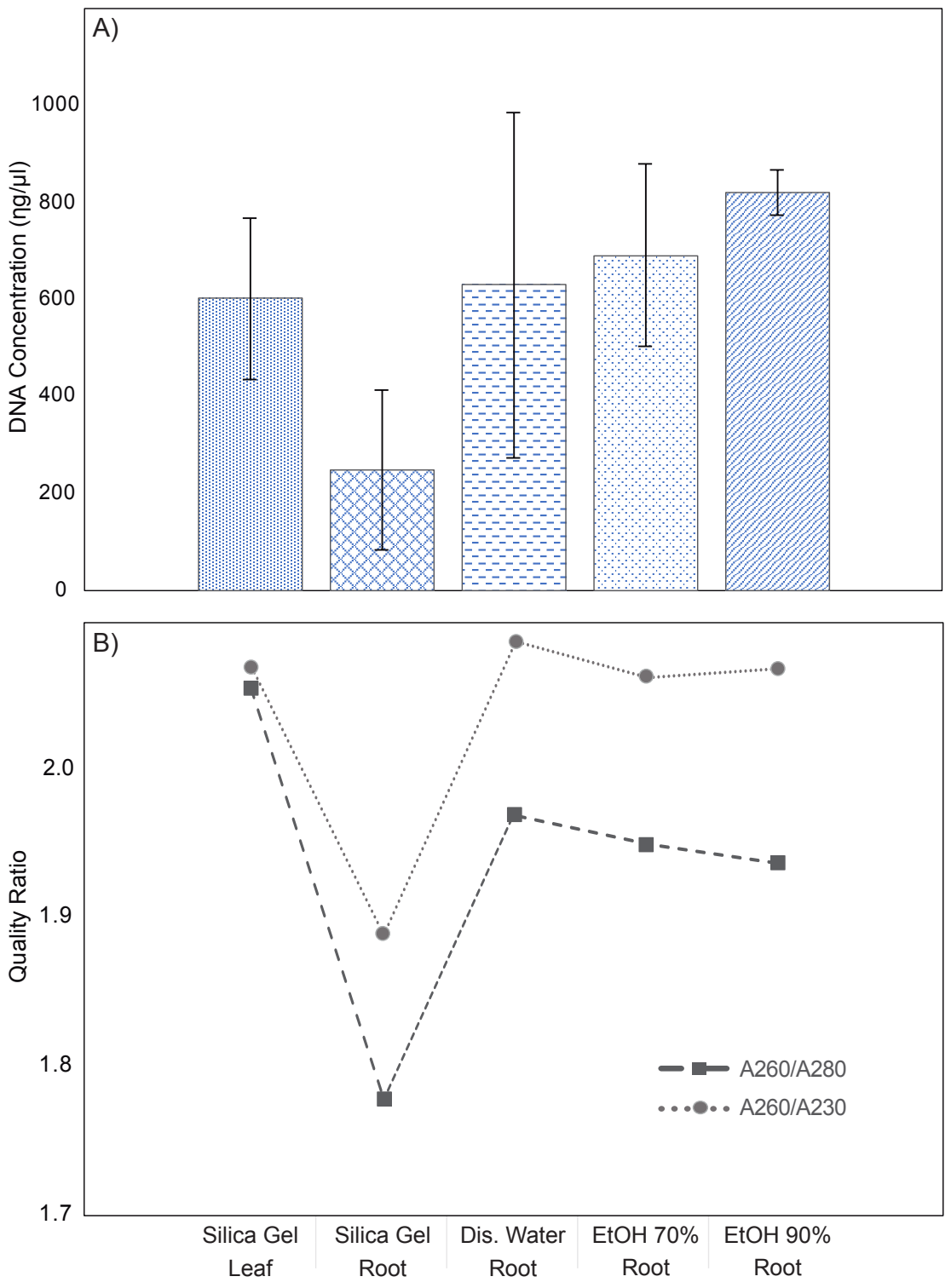